\title{
Who is steering the jurisprudence of the European Court of Justice? The influence of Member State submissions on copyright law
}

\author{
Marcella Favale, ${ }^{*}$ Martin Kretschmer ${ }^{\dagger}$ \\ and Paul L. C. Torremans ${ }^{\ddagger}$
}

\begin{abstract}
The juridification of the European policy process is increasingly fragile, and little understood. This study develops a novel methodology to investigate the influence of Member States on the rulings of the Court of Justice of the European Union (CJEU). The focus is on the domain of copyright law which has seen a dramatic escalation of preliminary references to the Court, indicating a normative void. Examining 170 documents relating to 42 cases registered between 1998 and 2015, we measure empirically the impact of submissions by Member States and the European Commission on the interpretation of copyright concepts. We show that France is the most influential country by some distance, both in terms of the number of interventions (an 'investment' in policy) and in terms of persuasive power (arguments adopted by the Court). The evidence also suggests that the departure of the UK from EU litigation will disturb the delicate balance of CJEU jurisprudence.
\end{abstract}

\section{INTRODUCTION}

The Court of Justice of the European Union (CJEU) plays a role quite unlike any other international court in what has been called 'a notable juridification of the European policy process'. ${ }^{1}$ In a time of potential disintegration, it has become more important than ever to understand how the Court performs its integrating role in a contested political environment. This requires an analysis that does not rely on the assumption of legal autonomy. We need to understand the forces that shape the behaviour of the Court of Justice beyond an analysis of the case law and the Court's evolving jurisprudence.

*Marcella Favale is Senior Research Fellow, Centre for Intellectual Property Policy and Management (CIPPM), Bournemouth University and the UK Copyright and Creative Economy Centre (CREATe).

${ }^{\dagger}$ Martin Kretschmer is Professor of Intellectual Property Law and Director of CREATe, University of Glasgow.

${ }^{\ddagger}$ Paul L. C. Torremans is Professor of Intellectual Property Law, University of Nottingham.

The research on which this article is based has been supported by CREATe, AHRC Grant Number AH/K000179/1 and by Martin Kretschmer's Fernand Braudel fellowship at the European University Institute (2018). We would like to thank the President of the CJEU, and in particular his chef de cabinet Mr Ignace Maselis; the Court Registry; Marie-Pierre Granger, Andreas Moberg, Jeff Carrubba; the agents and civil servants from all 16 Member States that made copyright submissions in the 42 cases coded and the European Commission (following a request under Regulation 1049/2001).

1 R. Dehousse, The European Court of Justice: The Politics of Judicial Integration (London: Macmillan, 1998) 177. 
Political science treats the possibility of autonomous action of the Court with scepticism, often suggesting that the Court's rulings are determined by the anticipated reactions of national governments. ${ }^{2}$ In this study, we develop an empirical approach that uses the window of Member States' written observations to investigate the influence of governments on the jurisprudence of the Court in one specific subject domain: copyright law.

In her pioneering research on the behaviour of governments before the Court, Marie-Pierre Granger ${ }^{3}$ argued that carrying out a study to measure the impact of governments' written observations was not feasible. It is certainly true that since 'written observations' are treated as 'confidential', and are no longer published in the Court proceedings, this task can appear daunting. However, in order to make a significant advance in understanding the role of national governments in relation to the Court of Justice, these obstacles need to be overcome.

Our core research question was initially anchored in the fast-moving domain of copyright law because the CJEU seemed to fill a normative void, with a dramatic escalation of cases. ${ }^{4}$ We were concerned with the possibility that the jurisprudence of the Court was open to capture, and that national governments may be able to steer the Court to produce policy outcomes that were politically unachievable.

Even though there are certain limitations to capturing all governments' written observations verbatim, we show that it is possible to assemble sufficient data to establish trends and construct a number of possible scenarios. With the assistance of supportive agents before the Court, the Court Registry, and Freedom of Information requests (both under Regulation 1049/2001 and national legislation), we have been able to produce a near comprehensive database of interventions and outcomes in 42 copyright cases before the Court of Justice. This allows a considerable advance in our knowledge (both methodologically and in substance) about the functioning of jurisprudence in the complex and elusive structure we call 'Europe'. For the first time, it is possible to see how Member States and the Commission are nudging the Court in a specific subject domain. Drawing on this picture, we can also simulate different scenarios prompted by Europe's unique geopolitical context, including the departure of the United Kingdom from the European Union.

The research underpinning this study is our previous work on the Court of Justice. ${ }^{5}$ Our earlier study investigated empirically two frequently made claims: first, that the Court failed to develop a coherent copyright jurisprudence

2 C.J. Carrubba, M. Gabel and C. Hankla, 'Judicial Behavior under Political Constraints: Evidence from the European Court of Justice' (2008) 102 Am Polit Sci Rev 435.

3 M.P. Granger, 'When governments go to Luxembourg ... the influence of governments on the Court of Justice' (2004) 39 EL Rev 1, 1. See also, generally, M.P. Granger, 'Les stratégies contentieuses des Etats devant la Cour' in P. Mbongo and A. Vauchez (eds), Dans la fabrique $d u$ droit européen (Bruxelles: Bruylant, 2009).

4 Preliminary references increased from six copyright cases filed in the 10 years following the Phil Collins case (C-92/92), six cases in the five years between 2002 and 2006, 21 cases in the five years between 2007 and 2011, to 43 cases between 2012 and 2015 .

5 M. Favale, M. Kretschmer, P. Torremans, 'Is there a EU Copyright Jurisprudence? An empirical analysis of the workings of the European Court of Justice' (2016) 79 MLR 31. 
(lacking domain expertise, copyright specific reasoning, and predictability) and second, that the Court pursued an activist, harmonising agenda (resorting to teleological interpretation of European law). We analysed the allocation of copyright and database right cases by Chambers of the Court, Advocate General (AG) and Reporting Judge, and investigated the biographical background of the Judges and AGs sitting. We also traced patterns of reasoning in the Court's approach through quantitative content analysis. We identified the legal topoi that were employed in the opinions and decisions, and then linked the occurrence of these topoi to the outcome of each case. The results showed that private law, and in particular intellectual property law expertise was almost entirely missing from the Court. However, we found that the Court had developed a mechanism for enabling judicial learning through the systematic assignment of cases to certain Judges and AGs. We also found that the Court had developed a 'fair balance' topos linked to Judge Malenovský (rapporteur on 24 out of then 40 copyright cases 1992-2012) that did not predict an agenda of upward harmonisation, with about half of judgments narrowing rather than widening the scope of copyright protection.

Our earlier study tried to lift the lid on how the CJEU works as a social body making copyright law. The focus of this new research moves from the judiciary to the role of governments in shaping the copyright jurisprudence of the Court.

There are considerable resources available from the political science literature on how to approach this question. In particular, empirical socio-legal research has suggested that while various organisations use strategic litigation (preliminary references) to steer judicial policy, ${ }^{6}$ Member States can use their interventions via written observations for the same purpose. ${ }^{7}$ According to some research, governments use participation in litigation to try to obtain favourable decisions ${ }^{8}$ because they understand that they can influence EU jurisprudence through well-written and well-argued observations. ${ }^{9} A$ fortiori, governments have realised that with successful interventions before the Court they can obtain the reversal of European policies that they opposed without success in the EU Council. ${ }^{10}$ However, other empirical research has suggested that the European judiciary is constrained in its rulings by fear of overturning or disapplication from the referring Member State, and that it acts accordingly. ${ }^{11}$

While the present study focusses on copyright case law, its methodological approach can be applied to any area of law before the CJEU. Indeed, the systematic analysis of briefs and submissions before a court is a promising and

6 H. Rasmussen, On Law and Policy in the European Court of Justice (Dordrecht: Martinus Nijoff, 1986) 270.

7 Granger 2004, n 3 above, 1.

8 J.H.H. Weiler, 'The Transformation of Europe' (1991) 100 Yale Law Journal 2403.

9 J. Collins, 'Representation of a Member State before the Court of Justice of the European Communities: practice in the United Kingdom' (2002) 27 EL Rev 359.

10 Granger 2004, n 3 above, 9.

$11 \mathrm{n} 2$ above, 9. On the same topic of the impact on CJEU decisions of possible Member States non-compliance, see also G. Garrett, R.D. Kelemen, and H. Schulz, 'The European Court of Justice, National Governments, and Legal Integration in the European Union' (1998) 52 International Organization 149. 
fast developing field of enquiry, opening a new perspective on the workings of the judiciary. ${ }^{12}$

After a brief overview of the copyright literature discussing the normative role of the CJEU and the way it addresses recurrent litigation on particularly controversial topics, the article empirically analyses the Court's copyright jurisprudence, to provide measurable answers to a number of instrumental sub-questions:

1. What are the most contested legal concepts in EU Copyright Law?

2. Who are the Governments interested in shaping copyright jurisprudence and, specifically, on which legal concepts are they intervening?

3. Which interests are Governments supporting (e.g. rightholders' or users')?

4. To what extent are Governments successful in steering the Court towards their interpretation of legal concepts?

The article proceeds as follows. Having set the context, our methodological approach will be explained and justified in the following section. The third section will provide the conceptual framework for analysing the normative role of the Court, using the example of the concept of 'communication to the public' to illustrate the implications. The fourth section will scope the legal concepts that recur most frequently in copyright litigation; this we assume is outlining a normative void. The fifth section identifies the countries that are most active in copyright litigation and the sixth presents and discusses our central empirical findings, quantifying the influence of each country before the Court and their relative position in favour of rightholders or users. The final section offers a conclusion, interpreting the findings for the "production of Europe'.

\section{METHODOLOGY}

This article extends methods used in our previous work and in previous social science research. Marie-Pierre Granger ${ }^{13}$ was first to study the litigation strategies of governments intending to have an impact on the jurisprudence of the Court of Justice. Her dataset includes the number of governments' written observations, the areas of intervention, and the number of interventions in preliminary references filed by a court of the same government in the years

12 Recent studies that reflect the empirical turn in copyright litigation research include H. Kalimo, T. Meyer and T. Mylly, 'Of Values and Legitimacy - Discourse Analytical Insights on the Copyright Case Law of the Court of Justice of the European Union' (2018) 81 MLR 282; T. Rendas, 'Copyright, Technology and the CJEU: An Empirical Study' (2018) 49 IIC International Review of Intellectual Property and Competition Law 153; E. Rosati, Copyright and the Court of Justice of the European Union (Oxford: OUP, 2019); M. Sag, 'Empirical studies of copyright litigation' in Research Handbook on the Economics of Intellectual Property Law (vol ii - analytical methods) (Northampton: Edward Elgar, 2019).

13 Granger 2004, n 3 above. 
between 1995 and 1999. Her methods included structured questionnaires and (qualitative) interviews of agents acting for governments.

Carrubba ${ }^{14}$ measured the impact of governments' observations on Court of Justice rulings involving the government as a litigator. In particular, the work measured how the threat of non-compliance (in national courts) or overriding (in the Council) influences the Court's decisions. To this end, he employed textual analysis (coding) of legal documents (cases between 1987 and 1997) and statistical analysis, including regression modelling of binary response variables (probit model). The document analysis involved coding the ruling and the written observations by capturing the preference of the government on each individual legal issue.

Cramér and colleagues ${ }^{15}$ also use content analysis (coding) of governments' written observations and preliminary reports ${ }^{16}$ before the CJEU between 1997 and 2008, and descriptive statistics. Unlike other research ${ }^{17}$ they break down the observations into legal arguments. The most interesting finding of this work is that the litigation behaviour of Member States is consistent with their government's economic model and therefore with their mainstream policies. Cramér et al's research also codes the relative position of countries as 'pro EU Integration' or 'pro National Sovereignty'. ${ }^{18}$

In our study, we use content analysis of documents (coding), a structured questionnaire recording governments' suggested answers (followed by unstructured feedback from agents and civil servants on our preliminary findings) and basic statistical computation of the data. The research design progressed in the following steps:

First, doctrinal analysis was used to identify groups of preliminary references demanding clarifications from the Court on the same copyright concept (for example, 'communication to the public'). The dataset, consisting of all 78 copyright cases registered between 1998 and 2015 (and concluded before the Court) was clustered on the basis of the main legal concept examined by each preliminary reference. The results show that more than half of all preliminary copyright references were filed on only five concepts, which therefore received more attention from the CJEU, indicating a potentially contested policy direction.

Secondly, the study employed content analysis (coding) on these 42 selected cases dealing with 'recurrent' concepts, to identify the arguments exposed in the written observations from Member States and the EU Commission, and their acceptance or rejection in the final ruling of the Court.

$14 \mathrm{n} 2$ above, 440 .

15 P. Cramér et al, 'See You in Luxembourg? EU Governments' Observations Under the Preliminary Reference Procedure' Swedish Institute for European Policy Studies SIEPS 2016:5 at http://www.sieps.se/en/publications/2016/see-you-in-luxembourg-eu-governments-observa tions-under-the-preliminary-reference-procedure-20165/ (last accessed 16 August 2018).

16 The preliminary report is an internal court document that is drafted by the Reporting Judge and it is circulated among the members of the chamber before the ruling. It has been published in the Court Repertoire until the year 2012.

17 B.A. Kilroy, Integration Through Law: ECJ and Governments in the EU (1999) PhD diss, University of California, Los Angeles.

18 n 15 above, 27. 
Thirdly, statistical analysis was deployed to establish relationships between the outcome of the case and the written observations. The analysis captures, first, the interests of governments in a particular legal concept; and second, the correlation of their submissions on the interpretation of individual copyright concepts with the outcome of the Court's decision in each case. Together they produce a measure of influence for each Member State.

To explore possible explanations for the observed patterns, finally, these findings were circulated among court agents and civil servants for feedback. This qualitative element allows a more subtle understanding of behaviour, and shapes the interpretation offered in our conclusions.

\section{Sample construction}

Our sample includes only preliminary references, in line with all cited previous research, because these are central to the question of juridification of the European copyright policy process. ${ }^{19}$ Within our initial population of all 78 copyright cases registered between 1998 and 2015, we identified 42 cases in which there was a 'recurrence' of the same legal issue (which we defined as five or more references to the CJEU on the same concept). The justification for reducing the sample to cases that dealt with concepts that were subject of repeat references is twofold. Pragmatically, it produced a manageable data set. More pertinently, the prevalence of certain legal issues within copyright law points to a normative void, i.e. a regulatory space within the acquis communautaire that stakeholders and governments are trying to fill with diverging policies. This could be seen as an alternative to legislative action, or as an opportunity to correct earlier legislation or case law. ${ }^{20}$

For these 42 'strategic' cases, 170 case documents were compiled, consisting of the published court documents (Advocate General's Opinion and the Court's Ruling) and the written submissions by the European Commission and Member States that chose to intervene. These are the primary sources of our study.

While the ruling and the AG Opinion for each case are available on the CJEU website ${ }^{21}$ government and Commission Submissions are not published. We first contacted the Court Registry in order to apply for access to these documents, although aware that the Court was not mentioned among the EU institutions subject to Regulation 1049/2001 regarding public access to official documents. ${ }^{22}$ We thought we could rely on a number of factors: a) the purpose of

19 Breach proceedings brought by the Commission against allegedly infringing Member States were excluded, $n 5$ above, 38 .

20 See generally on this point, J. Griffiths, 'Constitutionalising or harmonising? - the Court of Justice, the right to property and European copyright law' (2013) 38 EL Rev 65; and M. van Eechoud, 'Along the Road to Uniformity - Diverse Readings of the Court of Justice Judgments on Copyright Works' (2012) 3 JIPITEC 60.

21 http://curia.europa.eu/.

22 Regulation (EC) 1049/2001 of the European Parliament and of the Council of 30 May 2001 regarding public access to European Parliament, Council and Commission documents, OJEC L 145/43 31.05.2001. 
accessing the documents for scientific research; b) our willingness to enter a non-disclosure agreement; c) the justification for exclusion of judiciary documents in current EU and national regulations (it is central to the CJEU's own case law on Regulation 1049/2001 whether 'proceedings remain pending'). ${ }^{23}$ The Court Registry responded that they were unable to grant access to the requested documents because government submissions are 'confidential'. While the Registry provided a number of older 'Reports for the Hearing' which are compiled by the Reporting Judge in most cases (including suggested answers to multiple questions posed to the Court for a preliminary ruling), they were not prepared to explore new avenues for accessing 'written observations' by Member States.

We therefore had to employ a cumbersome data collection strategy that relied on obtaining submissions directly from the source. The European Commission is covered by Regulation 1049/2001, and Member States have national freedom of information legislation. ${ }^{24}$

Our first point of access was through Court Agents (acting on behalf of Member States) and civil servants instructing these agents. Many were extraordinarily helpful, but some were not. Where it was possible, we obtained answers to structured questionnaires recording each government's suggested answers to questions posed to the Court. We supplement these materials with documents received from other researchers ${ }^{25}$ who kindly shared their own data. We also reverse-engineered references to suggested answers from specific Member States as they appear in the published AG Opinions and Rulings of the Court. Gaps were filled by Freedom of Information requests to the

23 The CJEU considered the excludability of court pleadings from disclosure in Sweden v API, and concluded that judicial deeds can be excluded per se, because of the need to preserve the 'serenity of judgements' and 'equality of arms' (it cannot be that only one party to the case would be obliged to disclose). See joined cases C-528/07 P and C-532/07 P Sweden and Others v API and Commission [2010] ECLI:EU:C:2010:541 at [93], regarding a disclosure of Commission documents under Regulation 1049/2001 (not access to a Government's written observation). This case is interesting because the Court argues the rationale of EU legislation (from Art 255 TFEU to the Regulation) for the exclusion of judiciary deeds ('pleadings') from freedom of access. The CJEU specifies that its documents are rightly excluded from the Regulation 'while those proceedings remain pending'.

24 In EU member states, Freedom of Information Acts (FOIA) or equivalent laws provide for a fundamental freedom to access administrative documents in order to promote citizen participation in the democratic process. These documents normally refer to the deeds of the public administration, and typically provide for a number of exclusions, for example to protect the public interest, trade secrets, or privacy. Judicial proceedings are often excluded not per se, but only when the proceedings could be endangered by the disclosure. The British FOIA for example excludes access to administrative documents when justified by the need to preserve the administration of justice (Freedom of Information Act, s 31(1)(c)). The French corresponding law excludes the documents whose disclosure would harm judicial proceedings (Art L 311-5 1(f) III Livre of the Code des relations entre le public et l'administration). While it is arguable that possible harm can only occur during the proceedings, not after, not all FOIAs mention judicial proceedings among the exclusions. Italy, for example, does not include judicial proceedings among the exceptions listed in Art 24, L. n. 241/1990 ('Nuove norme in materia di procedimento amministrativo e di diritto di accesso ai documenti amministrativi' Gazzetta Ufficiale del 18 agosto 1990 n. 192, as modified by L. 15/2005). Other countries, such as the Scandinavians, grant full access to all public documents, including court proceedings, unless a superior interest is endangered.

25 See note * above and our acknowledgements. 
European Commission and various Member States. ${ }^{26}$ The final dataset contains 170 documents, with a total of 584 data points or observations on the selected 42 cases. The complete dataset of suggested answers by Member States, stratified by groups of 'recurrent concepts' can be found in Figure 8 below.

\section{THE NORMATIVE ROLE OF THE CJEU IN THE COPYRIGHT LITERATURE}

There is consensus in the literature that the Court of Justice is playing an increasingly central role in shaping not only the nuances but the contours of copyright law in Europe. Most academic analysis responds to specific rulings of the Court, often by means of individual case comments focussing on decisions that may be seen as seminal or affect wider sectoral interests. With the dramatic increase in preliminary references since about 2008, the copyright rulings of the Court also become traceable as an emerging body of jurisprudence, inviting transversal and evolutionary treatment across a range of cases. Competition practices have been analysed by Preck ${ }^{27}$ and Stuyck. ${ }^{28}$ Charter rights perspectives have been developed by Oliver and Stothers. ${ }^{29}$ The exclusive right of communication to the public ${ }^{30}$ has been extensively discussed. Copyright exceptions are explored by a number of authors, in particular, the reproduction for private copy and the related levies to provide fair compensation, ${ }^{31}$ the exception for parody ${ }^{32}$ and the exception for libraries. ${ }^{33}$

26 The lack of transparency about Member States' and the Commission's interventions before the Court remains troublesome and will be the subject of a separate article. There should not be a need for freedom of information requests nor subterfuge (such as reconstructing successful interventions from references to written observations in the Opinions of the Advocate General). In our sample of preliminary references, no government was a party, and access to legal submissions after proceedings are concluded cannot be said to weaken the position of parties during the process. In our view, a government's 'written observations' come close to proposals in a legislative process. They should be treated as such.

27 M. Prek and S. Lefevre, 'Competition Litigation before the General Court: Quality if not Quantity? (2016) 53 Common Market Law Review 65.

28 J. Stuyck, 'The Court of Justice and the Unfair Commercial Practice Directive' (2015) 52 Common Market Law Review 721.

29 P. J. Oliver and C. Stothers, 'Intellectual Property under the Charter: Are the Court's scales properly calibrated?' (2017) 54 Common Market Law Review 517.

30 Griffith, n 20 above, 13. See also E. Rosati 'Towards an EU-wide copyright? (Judicial) pride and (legislative) prejudice' 1 IPQ (2013) 47 at 11. See also, n 19 above, 74; M. Leistner, 'Europe's copyright law decade: Recent case law of the European Court of Justice and policy perspectives' (2014) 51 Common Market Law Review 559, 569; L. Bently et al, 'The Reference to the CJEU in Case C-466/12 Svensson' University of Cambridge Faculty of Law Legal Studies Research Paper Series, 6/2013 at https://papers.ssrn.com/sol3/papers.cfm?abstract_id=2220326 (last accessed $30^{\text {th }}$ of June 2019).

31 M. Kretschmer, Private Copying and Fair Compensation: An empirical study of copyright levies in Europe (London: Intellectual Property Office UK, 2011).

32 E. Rosati, 'Just a laughing matter? Why the decision in Deckmyn is broader than parody' (2015) 52 Common Market Law Review 511. See also The European Copyright Society's 'Opinion on the Judgment of the CJEU in Case C-201/13 Deckmyn' (2015) 37 EIPR 127.

33 E. Linklater, 'Make me an offer I won't regret: Offers to license works on acceptable terms cannot block libraries' 'right' to digitize for access on dedicated terminals: Technische Universität Darmstadt' (2015) 52 Common Market Law Review 813. 
Some scholars have taken issue with the so-called 'normative' role of the CJEU, stepping in when the law is not sufficiently clear or exhaustive. ${ }^{34}$ In our previous work ${ }^{35}$ we investigated the claims by this literature that the Court is pursuing a harmonising agenda, ${ }^{36}$ overstepping its mandate by an excessively teleological interpretation of the law.

These systematic studies of the emerging European Copyright jurisprudence are central to our discourse because they define the doctrinal landscape of copyright which our empirical study seeks to explain. Mireille van Eechoud, Andreas Rahmatian and Eleonora Rosati for example, in separate works, focussed on the originality requirement as defined by the Court in Infopaq and as confirmed in the following jurisprudence. ${ }^{37}$ Jonathan Griffiths and Martin Husovec analysed the role of fundamental rights in key cases addressing the liability of internet intermediaries. ${ }^{38}$ The most ambitious early analysis of the CJEU's copyright jurisprudence as a whole is Matthias Leistner's review of 2014. ${ }^{39}$

Leistner aims to locate the key issues of law discussed before the court in the full range of copyright cases, which together give shape to a new body of European copyright law. He examines the originality requirement, ${ }^{40}$ the reproduction right, ${ }^{41}$ the communication right,${ }^{42}$ the distribution right, ${ }^{43}$ digital exhaustion, ${ }^{44}$ copyright exceptions ${ }^{45}$ and fair compensation, ${ }^{46}$ as well as the specific concept of communication to the public. ${ }^{47} \mathrm{He}$ recognises both the horizontal range of the autonomous interpretation of copyright concepts and the vertical depth with which these concepts are discussed. The normative role of the Court, in his view, is a necessary complement of a legislative machine that has become more and more cumbersome. ${ }^{48}$ The activist role of the Courts with respect to copyright law should not be discouraged, but even supported by the use of preliminary references by Member States. ${ }^{49}$

The significance of the conceptual developments identified by Leistner is confirmed by our analysis which evidences a disproportionately high concentration of cases on these topics. In Appendix II (see Supporting Information), we have listed the doctrinal pressures chronologically for the five key concepts

34 See generally, Griffiths, n 20 above and van Eechoud, n 20 above.

35 n 5 above, 36 .

36 Griffith, n 20 above, 24; van Eechoud, n 20 above, 77; Leistner, n 30 above, 595.

37 See generally, van Eechoud, ibid and Rosati, n 32 above. See also A. Rahmatian, 'Originality in UK Copyright Law: The Old "Skill and Labour" Doctrine Under Pressure' (2013) 44 International Review of Intellectual Property and Competition Law 4.

38 Griffiths, n 19 above; M. Husovec, Injunctions Against Intermediaries in the European Union (Cambridge: CUP, 2017).

39 n 30 above.

40 ibid, 564 .

41 ibid, 569.

42 ibid, 569 .

43 ibid, 574.

44 ibid, 574.

45 ibid, 584 .

46 ibid, 586.

47 ibid, 592.

48 Leistner argues that the active role of the Court reflects the 'hydraulics of powers' under which the EU's legislative role is waning, ibid, 599.

49 ibid, 599. 
we identified empirically as recurrent. These are: 1) Communication to the public, 2) Copyright exceptions, 3) Levies (fair compensation for private use), 4) Distribution Right, and 5) Liability of Intermediaries. All other legal issues have four or less occurrences within the sample of 78 preliminary references. ${ }^{50}$

Most prominence is given to the concept of 'communication to the public', whose evolution through the jurisprudence of the CJEU provides a telling example of the Court's normative role. In the following section, we use the concept of 'communication to the public' in order to elaborate the scope for competing interpretations, and the market effects they might have. This is important in order to understand what is at stake in the potential influence exercised by Member States through their submissions. We selected the concept of 'communication to the public' because it is the most frequently appearing copyright issue before the CJEU (it is engaged 15 times in our sample). It is therefore possible to trace the normative concept and its development through a considerable number of cases. Each choice made by the Court will have an impact on the parties concerned, and Member States may have tried to convince the CJEU in their submissions to go down alternative doctrinal paths.

\section{The concept of 'communication to the public'}

The question 'who steers the development of law' presupposes that the law is indeterminate or offers sufficient flexibility for jurisprudence to take different directions. These different directions will have both doctrinal and societal consequences. We now illustrate this claim, using the specific example of the concept of 'communication to the public'. This enables an understanding of the scope for intervention by Member States through submitting so-called 'written observations', i.e. a legal analysis with suggested answers to the questions posed to the Court. ${ }^{51}$

The main EU provision regarding the exclusive right of communication to the public is found in Article 3 of Directive 2001/29. ${ }^{52}$ Three elements are included in the definition of a communication to the public: (i) it can take place by wire or through wireless means, (ii) including on demand services, and (iii) any communication to the public of the work is included in the exclusive right to authorise such communication to the public that is given to the author. All other elements and questions surrounding the concept of communication to the public and how it applies in a modern setting are left undefined.

50 Detailed descriptive statistics can be found in the next section below.

51 The rules of procedure of the Court of Justice are summarised in Appendix I (see Supporting Information).

52 Directive 2001/29/EC of the European Parliament and of the Council of 22 May 2001 on the harmonization of certain aspects of copyright and related rights in the information society [2001] OJ L 167/10. 
The international instruments, such as the Berne Convention ${ }^{53}$ and the WIPO Copyright Treaty $1996^{54}$ (which Article 3 is implementing) do not add much detail either. That leaves plenty to play for in the interpretation of the concept. The CJEU was therefore obliged to fill the gaps and make a significant number of choices when it developed the normative framework. Each of these choices is more favourable to the position of one of the parties than to the position of another, and the Member States may have tried to influence these choices. We will now proceed to illustrate this in a non-exhaustive way, before we embark on the systematic analysis of the submissions of the Member States and their impact on the CJEU's copyright case law.

In a digital online environment, there is scope for rebroadcasting of many sorts. Hotels (and spas, clinics, etc) have for years made centrally received broadcasts available in individual hotel rooms and lobbies, but in the same vein it is now possible to pick up a signal and stream it online, in real time or in delayed and edited format. Do these activities involve a new act of communication to the public and is there a new authorisation that needs to be paid for? Or is there, in all or in some of these circumstances, merely one original communication to the public? ${ }^{55}$ Broadcasters and hotel owners, if we refer only to these by way of example, have opposite interests on this point. A narrow definition of communication to the public would favour the hotels and with them the national government that wants primarily to encourage the tourism industry. Those in favour of the content providing industry would on the other hand favour a broad interpretation. And whatever the answer the Court eventually gave, a slight change in (technological) circumstances would mean that parties had an incentive to go back to the Court in the hope of obtaining a different answer that favoured their interests.

Similarly, how do we deal with hypertext links? Does the provision of such a link involve a new communication to the public of the copyright work that is found at the location to which the link directs the user? Parties with very different interests have an incentive to return to the Court to obtain a slightly different answer when new technologies emerge.

So how did the 'communication to the public' case law of the Court take shape? In the view of the Grand Chamber, who dealt with this topic in Reha Training Gesellschaft für Sport- und Unfallrehabilitation $m b H \vee$ Gesellschaft für musikalische Aufführungs- und mechanische Vervielfältigungsrechte eV (GEMA) ${ }^{56}$ (Reha Training) (a case concerning the playing of music on TV sets installed in a rehabilitation centre) in the aftermath of various judgments touching upon the topic, there are several complementary criteria, which are not autonomous

53 Berne Convention for the Protection of Literary and Artistic Works 1886 at http://www. wipo.int/wipolex/en/treaties/text.jsp?file_id=283693 (last accessed 2 December 2019).

54 WIPO Copyright Treaty 1996 at https://wipolex.wipo.int/en/text/295157 (last accessed 2 December 2019).

55 The Austrian and Irish governments submitted in SGAE that the mere installation of equipment in rooms did not constitute an act of communication to the public. Opinion of Advocate General Sharpston in case C-306/05 Sociedad General de Autores y Editores de España (SGAE) v Rafael Hoteles SA ECLI:EU:C:2006:479 at [26].

56 Case C-117/15 Reha Training Gesellschaft für Sport- und Unfallrehabilitation mbH v Gesellschaft für musikalische Aufführungs- und mechanische Vervielfältigungsrechte eV (GEMA) ECLI:EU:C:2016:379. 
and which are interdependent. Depending on the circumstances of the case these factors may be present to widely varying degrees. As we shall see, these criteria appeared at different stages in the development of the Court's case law and favour the position of different parties. The Grand Chamber is trying to bring the criteria together in an overall framework, pointing to Phonographic Performance (Ireland) Limited v Ireland, Attorney General ${ }^{57}$ (Phonographic Performance), where the Court ruled in favour of a (new) communication to the public in the hotel and therefore in favour of the rightholders by using certain of the criteria, whilst on the very same day favouring other criteria in Società Consortile Fonografici (SCF) v Marco Del Corso ${ }^{58}$ (SCF) (a case concerning the status of music played in a dentist's writing room). In SCF the Court held that no communication to the public took place in a dental practice and hence favoured the position of users. This latter SCF case shows clearly the attempts of the Member States to use their submissions to have an impact on the normative developments. The French government argued strenuously in favour of there being a communication to the public on the basis of the dentist playing the music and therefore communicating the work to the public and on the basis that eventually there would be enough listeners as patients visit the surgery. The latter point was given less importance in these submissions. Such an approach would, of course, favour rightholders. The CJEU did not accept this submission and held any such communication to be de minimis. Here the CJEU was clearly more convinced by the submission of the Italian government that the playing of the music by the dentist was of no economic importance and was not part of his economic activity. ${ }^{59}$ By accepting these submissions and holding that the activity did not amount to a communication to the public the CJEU rather favoured the users of copyright works.

In the argument, the Grand Chamber takes as a starting point that there has to be both an act of communication and the communication of the work has to be to a public. This is illustrated with the SBS Belgium $N V \mathrm{v}$ Belgische Vereniging van Auteurs, Componisten en Uitgevers $(S A B A M)^{60}$ (SBS Belgium) case where the scenario of direct injection of broadcasts yielded an act of communication on behalf of the broadcasting stations, but no public. There was also an act of communication (and communication to the public overall) when add-ons that gave access to works without permission were pre-installed on a multimedia player. ${ }^{61}$ On this point the Commission had repeatedly made submissions to the CJEU that the act of communication presupposed that the work was communicated to persons that are not present at the place of transmission. ${ }^{62}$ The emphasis on the (pre-)installation of the add-ons, with the assumption that it is likely that a number of buyers will use them and receive access to

57 Case C-162/10 Phonographic Performance (Ireland) Limited v Ireland, Attorney General ECLI:EU:C:2012:141.

58 Case C-135/10 Società Consortile Fonografici (SCF) v Marco Del Corso ECLI:EU:C:2012:140.

59 Opinion of Advocate General Trstenjak in Case C-135/10 Società Consortile Fonografici (SCF) v Marco Del Corso ECLI:EU:C:2011:431 at [49] et seq.

60 Case C-325/14 SBS Belgium NV v Belgische Vereniging van Auteurs, Componisten en Uitgevers (SABAM) ECLI:EU:C:2015:764.

61 Case C-527/15 Stichting Brein v Wullems ECLI:EU:C:2017:300.

62 Opinion of Advocate General Trstenjak in SCF n 59 above at [49] et seq. 
the work (thus forming the public), can be seen as the successful result of the repeated submission by the French government emphasising the fact that there is a communication to the public if played or given access to a number of individuals, some of which may eventually take advantage of the option. ${ }^{63}$ Such a broad approach favours rightholders over users.

An act of communication refers to any transmission of protected works, irrespective of the technical means or process used. Any transmission or retransmission which uses a specific technical means must be separately authorised. Here the Court favours the interests of rightholders. ITV Broadcasting Ltd and Others v TVCatch $U p L t d^{64}$ is a clear example of a case where parties returned to the Court to try and include, or exclude depending on the party concerned, online streaming of a television broadcast from the concept of an act of communication. Retransmission by internet streaming was eventually held to amount to a communication to the public in the latter case. ${ }^{65}$

Secondly, the work must be communicated to the public. From the older cases, such as Sociedad General de Autores y Editores de España (SGAE) v Rafael Hoteles $S A^{66}$ (SGAE), the Grand Chamber takes the basic idea that the concept of a public involves an indeterminate number of potential recipients and a fairly large number of persons (as submitted in that case by the French and Polish governments ${ }^{67}$ ), only to qualify that immediately with the teaching of $S C F^{68}$ that the work must be made available in any appropriate manner to "persons in general'. Individuals belonging to a private group can be excluded, as can be small or insignificant groups. The size of the audience is determined in the light of the potential cumulative effect of there being various audiences, either a large group at the same time or individuals or small groups in succession. ${ }^{69}$

The Grand Chamber then also refers to the requirement of there being a new public, i.e. a public not taken into account by the rightholders when they authorised the original communication to the public. This is where the line of cases involving the operators of cafes, restaurants, hotels and spas (and now also rehabilitation clinics) comes in. In each of these cases the Court held that there was a new public, but there was no public in the $S C F$ case in dentist Del Corso's waiting room. And neither was there a new public in the leading case in the sub-clusters of internet hypertext link cases, Nils Svensson and Others $\mathrm{v}$ Retriever Sverige $A B^{70}$ (Svensson), that dealt with the inclusion on a company's website of clickable Internet links (hyperlinks) redirecting users to press articles

63 ibid at [59].

64 Case C-607/11 ITV Broadcasting Ltd and Others v TVCatchUp Ltd ECLI:EU:C:2013:147 (ITV Broadcasting).

65 Case C-275/15 ITV v TV Catchup Ltd ECLI:EU:C:2017:144 at [23].

66 Case C-306/05 Sociedad General de Autores y Editores de España (SGAE) v Rafael Hoteles SA ECLI:EU:C:2006:764.

67 Opinion of Advocate General Sharpston in case C-306/05 Sociedad General de Autores y Editores de España (SGAE) v Rafael Hoteles SA ECLI:EU:C:2006:479 at [33].

68 Reha Training n 56 above.

69 On the point of there being a public, see also case C-265/16 VCAST v RTI SpA ECLI:EU:C:2017:913.

70 Case C-466/12 Nils Svensson and Others v Retriever Sverige AB ECLI:EU:C:2014:76. The analysis was confirmed in case C-301/15 Soulier and Doke v Ministère de la Culture et de la Communication ECLI:EU:C:2016:878 at [36]. 
in which the applicants (Mr Svensson and his colleagues) held the copyright. The work linked had already been communicated to all internet users and the link, whilst involving an act of communication, could not reach a new public. Other cases then followed to see e.g., whether the same logic applied to framing scenarios. ${ }^{71}$ That was held to be the case, but on the other hand the posting on one website of a photograph previously posted on another website, without any restriction preventing it from being downloaded and with the consent of the copyright holder, did amount to a communication to the public and was distinguished from the hyperlinking scenario. ${ }^{72}$

Further criteria highlighted by the Grand Chamber include the profitmaking nature of the broadcast or rebroadcast involved and the receptivity of the public. Still, the German government argued successfully that receptivity of the public does not determine the profit making nature of the broadcast. It is merely a relevant factor. ${ }^{73}$ What becomes clear from the Grand Chamber's attempt to propose a comprehensive approach is that in different cases different criteria will play a vital role. ${ }^{74}$ The emphasis will not only be placed on different points, there is also clear evidence that the Court brought in additional factors as its case law developed. These criteria and their weighing will determine whether in a particular case there is a communication to the public or not and whose interests will eventually prevail. That point was again brought home by the Court's second chamber in GS Media BV v Sanoma Media Netherlands BV and others (GS Media), when the for-profit argument and the knowledge point were emphasised and it was stated that

in order to establish whether the fact of posting, on a website, hyperlinks to protected works, which are freely available on another website without the consent of the copyright holder, constitutes a 'communication to the public' within the meaning of that provision, it is to be determined whether those links are provided without the pursuit of financial gain by a person who did not know or could not reasonably have known the illegal nature of the publication of those works on that other website or whether, on the contrary, those links are provided for such a purpose, a situation in which that knowledge must be presumed. ${ }^{75}$

In this respect the German and Portuguese governments had submitted that there was no communication to the public and that subjective factors should not be taken into account. The French government on the other hand had submitted that there was a communication to the public on the basis that the

71 See the order in case C-348/13 BestWater International GmbHv Michael Mebes and Stefan Potsch ECLI:EU:C:2014:2315.

72 As it was, amongst other reasons, not required for the sound operation of the Internet. Case C-161/17 Land Nordrhein -Westfalen v Dirk Renckhoff ECLI:EU:C:2018:634.

73 Conclusion of Advocate General Bot in case C-117/15 Reha Training Gesellschaft für Sport- und Unfallrehabilitation mbH v Gesellschaft für musikalische Aufführungs- und mechanische Vervielfältigungsrechte $\mathrm{eV}$ (GEMA) ECLI:EU:C:2016:109 at [67] and [50] of the judgment at $\mathrm{n}$ 56 above.

74 The need for an individual assessment was confirmed in case C-527/15 Stichting Brein v Wullems ECLI:EU:C:2017:300.

75 Case C-160/15 GS Media BV v Sanoma Media Netherlands BV and others ECLI:EU:C:2016:644 at [55]. 
acts involved facilitated access to the material that was already on the Internet. ${ }^{76}$ This financial gain and knowledge element was also important when the Court held that the operation of a sharing platform that through indexing data gave users access to copyright works amounted to a communication to the public. ${ }^{77}$

The crucial point for this study is that we aim to determine whether the observations submitted by the parties (including their repeat submissions if cases and follow-on cases are brought deliberately) have influenced the development of the Court's case law. This may provide indications of a deliberate strategy to bring cases to steer or alter the evolution of the case law of the Court.

\section{RECURRENT CONCEPTS IN COPYRIGHT LITIGATION}

Having demonstrated for one central concept of EU copyright law how reasoning may be shaped, favouring one party or another, we now explain our selection of concepts for detailed empirical investigation. We reduced the complete population of 78 copyright cases (registered between 1998 and 2015) to 42 copyright cases that ruled on concepts that had been referred to the CJEU five times or more (which we term 'recurrent' concepts). We assume that these repeat references are an indication of a contested policy direction or a normative void, i.e. an opportunity by litigators and Member States to steer the evolving jurisprudence of the Court. This section identifies these cases and analyses which Member States appear to intervene on which underlying concepts.

To this end, we have compiled two datasets: one in which we have coded the main issue discussed in each case, and one in which we have captured suggested answers to all questions referred to the Court for a preliminary ruling in each case. The dataset in which each case is coded according to the main issue discussed allows a computation of the number of written observations submitted by each country. This becomes a measure of the interest of Member States in specific legal issues. Combined with the dataset coding suggested answers, this allows establishing a correlation of written observations with the interpretation given in the ruling.

Our empirical analysis of copyright litigation starts with the identification of the most common legal concepts submitted to the attention of the Court. Five clusters of legal issues emerge as dominant in the sample. These are: 1) Communication to the public, 2) Copyright exceptions, 3) Levies (fair compensation for private use), 4) Distribution Rights, 5) Liability of Intermediaries. In grouping legal concepts into these clusters we inevitably brush over doctrinal detail, for example the case law on copyright exceptions (referring to Article 5 InfoSoc Directive ${ }^{78}$ ) covers such diverse issues as technical network

76 Opinion of Advocate General Wathelet in case C-160/15 GS Media BV v Sanoma Media Netherlands BV and others ECLI:EU:C:2016:221 at [22]-[31].

77 Case C-610/15 Stichting Brein v Ziggo ECLI:EU:C:2017:456.

78 Directive 2001/29/EC of the European Parliament and of the Council of 22 May 2001 on the harmonisation of certain aspects of copyright and related rights in the information society, OJ L 167, 22.6.2001, 10-19. 
copies $\left(\right.$ Infopaq $\left.q^{79}\right)$, library photocopying (Technische Universität Darmstadt ${ }^{80}$ ), and parody $\left(\right.$ Deckmyn $\left.n^{81}\right)$. However, it is reassuring that the copyright literature reviewed above confirms that the five legal concepts clustered here are indeed those of greatest doctrinal interest.

Figures 1 and 2 offer descriptive statistics identifying the most common legal concepts discussed before the Court. The cases were coded according to all copyright legal issues brought within each case. Cases often discuss multiple concepts. This identifies a total of 51 occurrences of the five 'recurrent' concepts within the 42 cases.

\begin{tabular}{|l|r|r|r|r|}
\hline Legal Concept as Main Issue & Occurr & \%TOT & Subm N & $\%$ TOT \\
\hline A3-A8 Communication to the public & 15 & $19,2 \%$ & 58 & $17,6 \%$ \\
\hline A5.2(b) Fair compensation Private Use & 9 & $11,5 \%$ & 60 & $18,2 \%$ \\
\hline A5 Exceptions & 6 & $7,7 \%$ & 20 & $6,1 \%$ \\
\hline A4 Distribution Right & 6 & $7,7 \%$ & 17 & $5,2 \%$ \\
\hline A8 Intermediaries & 6 & $7,7 \%$ & 30 & $9,1 \%$ \\
\hline Others & $>=3$ & $<5 \%$ & & \\
\hline TOT Cases & & & & \\
TOT Cases w Recurrent Concepts (CRC) & 48 & & & \\
TOT Submissions & 330 & $54 \%$ & & \\
TOT Submissions in CRC & 185 & $56 \%$ & & \\
TOT Average Ref/Sub & 0,64 & & & \\
TOT Cluster Av. Ref/Sub & 0,69 & & & \\
\hline
\end{tabular}

Figure 1: Recurrent Legal Concepts as the Main Issue in CJEU Copyright Preliminary References [Colour figure can be viewed at wileyonlinelibrary.com]

\begin{tabular}{|l|r|r|}
\hline Most Recurrent Legal Concepts & Occurr & \%TOT \\
\hline A3-A8-A2 Communication to the public & 17 & $33,3 \%$ \\
\hline A5 Exceptions & 11 & $21,6 \%$ \\
\hline A5.2(b) Fair compensation Private Use & 9 & $17,6 \%$ \\
\hline A4 Distribution Right & 8 & $15,7 \%$ \\
\hline A8 Intermediaries & 6 & $11,8 \%$ \\
\hline Others & $<=4$ & $7,8 \%$ \\
\hline \multicolumn{2}{|l|}{} \\
\hline TOT Cases on Copyright & 78 & \\
TOT Occurrence of Legal Concepts & 51 & \\
TOT Cases with the above Legal Issues & 42 \\
\hline
\end{tabular}

Figure 2: Recurrent Legal Concepts in CJEU Copyright Preliminary References [Colour figure can be viewed at wileyonlinelibrary.com]

The concept of Communication to the public, recalled in discussions surrounding Article 3 of the InfoSoc Directive, Article 8 of the Rental and Lending Rights Directive, and Article 2 of the Satellite Broadcasting Directive, is the most discussed, with 15 cases that refer it as the main issue. The issue of Levies, including discussions on the definition, quantification and sources of the fair compensation for private reproduction (Article 5.2(b) of the InfoSoc Directive) follows with nine cases.

79 C-5/08 Infopaq International ECLI:EU:C:2009:465.

80 C-117/13 Eugen Ulmer ECLI:EU:C:2014:2196.

81 C-201/13 Deckmyn ECLI:EU:C:2014:2132. 
However, if we consider the total number of submissions (i.e. attempts to influence the outcome) in cases in which the above two are the main legal concept discussed, we see that Fair compensation leads, followed by Communication to the public. It is also interesting to compare the sum of the submissions elicited by these two legal issues (Communication to the public, and Levies), which outruns the sum of the submissions elicited by the other three legal issues. This indicates that parties to the litigation think most is to be gained from steering the Court on these issues. Moreover, it is notable that while litigation on Copyright Exceptions and the Distribution right has occurred more often than preliminary references on the potential liability of Internet Intermediaries (e.g., filtering or monitoring obligations for service providers) the total number of submission for the latter outnumbers the former by a ratio of 30:17. The stakes appear to be higher.

We need to consider that Member States do not have a say on what cases will be sent before the CJEU, as this is decided by national judiciaries. ${ }^{82}$ However, it is entirely at the governments' discretion to submit written observations in a given case. ${ }^{83}$ Therefore we assume that the total number of submissions on a given legal concept can serve as one indicator of the interest of Member States in that issue. This figure however needs to be adjusted to other indicators, as the next section shows.

\section{LITIGATION BEHAVIOUR OF MEMBER STATES: REPEAT PLAYERS IN COPYRIGHT}

We now shall examine in depth who are the most active governments in submitting legal observations before the Court and explore their interest in specific copyright issues. According to previous research, it is clear that governments use participation in litigation to try to obtain favourable decisions because they understand that they can influence EU jurisprudence through good written observations. ${ }^{84}$ Moreover, governments have realised that with a

82 However, it has been surmised that there may be collusion in some cases being 'pushed' before the court in order to foster discussion on certain subject-matters. See generally $O$. Amado et al, 'Lobbying at the European Court of Justice? Yes, we can!' paper for Daniel Guéguen's lecture 'Interest groups and Lobbies in the European Union' POLI-O505 (Brussels: Institute for European Studies 2012) at http://www.pacteurope.eu/pact/wp-content/ uploads/2012/06/Lobbying-at-the-European-Court-of-Justice.pdf (last accessed 25 October 2016).

83 Some Member States intervene routinely in cases where the preliminary reference comes from their own country. The more strategic governments appear to intervene also in cases which do not directly involve their own country. For further discussion of this point, see the next section below.

84 L. Conant, Justice Contained: Law and Politics in the European Union (Ithaca, NY: Cornell University Press, 2002) 23; see also, generally, A. Cullen and H. Charlesworth, 'Diplomacy by other means: the use of legal basis litigation as a political strategy by the European Parliament and Member States' (1999) 36 Common Market Law Review 1243. 


\begin{tabular}{|l|r|r|r|}
\hline & \multicolumn{1}{|c|}{ A } & B & C \\
\hline Country & Submissions & PR & PR+Sub \\
\hline FR & 24 & 4 & 4 \\
\hline CZ & 11 & 2 & 2 \\
\hline FI & 14 & 1 & 1 \\
\hline EL & 6 & 1 & 1 \\
\hline IE & 7 & 1 & 1 \\
\hline HU & 3 & 1 & 1 \\
\hline RO & 2 & 1 & 1 \\
\hline PL & 15 & 0 & 0 \\
\hline PT & 12 & 0 & 0 \\
\hline LT & 4 & 0 & 0 \\
\hline CH & 1 & 0 & 0 \\
\hline NO & 1 & 0 & 0 \\
\hline IT & 24 & 4 & 3 \\
\hline UK & 19 & 6 & 4 \\
\hline ES & 17 & 5 & 3 \\
\hline DE & 16 & 12 & 6 \\
\hline AT & 15 & 5 & 4 \\
\hline BE & 10 & 9 & 5 \\
\hline NL & 10 & 7 & 2 \\
\hline MT & 1 & 1 & 1 \\
\hline SK & 1 & 1 & 1 \\
\hline BG & 1 & 1 & 1 \\
\hline SE & 2 & 4 & 1 \\
\hline DK & 1 & 6 & 1 \\
\hline & & \\
\hline
\end{tabular}

\begin{tabular}{|ll|}
$\mathrm{B}=\mathrm{C}<\mathrm{A}$ & $\begin{array}{l}\text { Always intervene when } \mathrm{PR} \\
\text { from own Country, but also in } \\
\text { other PR }\end{array}$ \\
$\mathrm{C}<\mathrm{B}<\mathrm{A}$ & $\begin{array}{l}\text { Not Always intervenes } \\
\text { when PR from own Country, } \\
\text { but also in other PR }\end{array}$ \\
$\mathrm{A}=\mathrm{B}=\mathrm{C}$ & $\begin{array}{l}\text { Only and Always intervenes } \\
\text { when PR from own Country }\end{array}$ \\
$\mathrm{A}=\mathrm{C}<\mathrm{B}$ & $\begin{array}{l}\text { Only but Not Always } \\
\text { intervenes when } \mathrm{PR} \\
\text { from own Country }\end{array}$ \\
\hline
\end{tabular}

PR: Preliminary Reference

PR+Sub: Preliminary Reference AND

Submission from originating Country

Figure 3: Copyright Repeat Players [Colour figure can be viewed at wileyonlinelibrary.com]

successful written observation before the Court they can obtain the reversal of European acts that they have opposed without success in the EU Council. ${ }^{85}$

At first sight, the number of written observations in preliminary references points to the Member States most invested in copyright litigation before the Court. We have computed these written observations by country, obtaining a ranking of these countries. France and Italy seem the most invested, followed by the UK and then Spain, Poland, Germany, Austria, Finland, Poland, Czech Republic, Belgium and the Netherlands. However, previous research ${ }^{86}$ suggests that in order to identify the most strategic countries we need to control for the number of written observations in their own preliminary references. In fact, some national litigation offices are mandated by the central government to intervene in all preliminary references submitted from their own countries. It is therefore important to understand to what extent governments' interventions derive from preliminary references originating from their own country. Figure 3 captures the relationship between the number of written observations responding to a country's own preliminary references and the overall number

85 M.P. Granger, 'States as Successful Litigants before the European Court of Justice: Lessons from the 'Repeat Players' of European Litigation' (2006) 2 CYELP 27, 33.

86 Granger 2004, n 3 above, 3. 
of this country's observations. ${ }^{87}$ Arguably this indicates which countries behave most strategically.

The comparison between a) the number of written observations submitted by one country, b) the number of preliminary references originating from that country, and c) the number of submissions by this country when preliminary references are originating from the same country, produces insights about the propensity to litigation of the various Member States. When for example the number of preliminary references is equal to the number of submissions in their own preliminary references and higher than the submissions in other cases, there is a propensity to litigation which is directly proportional to the number of 'external' submissions. This indicates a likely mandate by this government to intervene in their own country's preliminary references, but it is also invested in litigation irrespective of this mandate. When however, other variables being equal, the number of submissions responding to preliminary references originating from their own country is lower, this indicates that this government is conscious of the effects of preliminary references in its own country, and therefore tends to intervene selectively even if not mandated. We argue that this indicates an investment in litigation according to policy interest, pointing to more strategic behaviour. The more a government intervenes in preliminary references originating from other countries, the more strategic the litigation behaviour. ${ }^{88}$

\section{Control: Total CJEU litigation for the same period}

The analysis above needs to be controlled for a number of factors, such as the size of a country's economy (gross domestic product, GDP) and overall propensity to litigate before the Court of Justice. In Figure 4, the number of interventions in all copyright cases (population of 78 cases registered 19982015 ) is displayed next to the GDP of each country. We can observe that the litigation activity of governments is not always proportional to their country's GDP. For example, Germany and the Netherlands display a low number of interventions despite their relatively high wealth. For other countries however the relation between propensity to litigation and size of economy is more evident, for example for France, Italy and the UK.

The overall propensity to litigation on the acquis communautaire of copyright needs to be understood within the context of the overall investment in litigation of each member state before the CJEU. Figure 5 compares the overall number of submissions in concluded preliminary references by EU Member States for

87 Tables in this article refer to countries by standardised two letter codes. We follow the European Commission's use (ISO 3166 standard with two variations: EL (not GR) represents Greece; UK (not GB) represents the United Kingdom).

88 EEA (European Economic Area) and EFTA (European Free Trade Association) members such as Norway (EEA and EFTA) and Switzerland (EFTA) have standing to submit written observations to the Court of Justice in some cases (see Appendix I, Supporting Information, on the rules of procedure of the CJEU). However, their own national courts cannot make preliminary references, as they are not members of the European Union. These countries have been omitted from further analysis. 
The Influence of Member State Submissions on Copyright Law

\begin{tabular}{|r|l|r|r|r|l|l|}
\hline Rank & Country & $\mathbf{2 0 1 6}$ & & Rank & Country & Submissions \\
\hline 1 & DE & $3,494.898$ & & 1 & IT & 24 \\
\hline 2 & UK & $2,649.893$ & & 2 & FR & 24 \\
\hline 3 & FR & $2,488.284$ & & 3 & UK & 19 \\
\hline 4 & IT & $1,852.499$ & & 4 & $\mathrm{ES}$ & 17 \\
\hline 6 & $\mathrm{ES}$ & $1,252.163$ & & 5 & $\mathrm{PL}$ & 15 \\
\hline 7 & $\mathrm{NL}$ & 769.930 & & 6 & $\mathrm{DE}$ & 16 \\
\hline 11 & $\mathrm{PL}$ & 473.501 & & 7 & $\mathrm{AT}$ & 15 \\
\hline 12 & $\mathrm{BE}$ & 465.248 & & 8 & $\mathrm{FI}$ & 14 \\
\hline 13 & $\mathrm{AT}$ & 384.799 & & 9 & $\mathrm{PT}$ & 12 \\
\hline 16 & $\mathrm{IE}$ & 254.596 & & 10 & $\mathrm{CZ}$ & 11 \\
\hline 17 & $\mathrm{FI}$ & 234.578 & & 11 & $\mathrm{BE}$ & 10 \\
\hline 18 & $\mathrm{PT}$ & 205.085 & & 12 & $\mathrm{NL}$ & 10 \\
\hline 19 & $\mathrm{EL}$ & 194.594 & & 13 & $\mathrm{EL}$ & 6 \\
\hline 20 & $\mathrm{CZ}$ & 185.269 & & 14 & $\mathrm{IE}$ & 7 \\
\hline 22 & $\mathrm{HU}$ & 117.729 & & 15 & $\mathrm{HU}$ & 3 \\
\hline
\end{tabular}

Figure 4: Ranking of Member States by GDP (US\$ billion) and by number of interventions in Copyright litigation [Colour figure can be viewed at wileyonlinelibrary.com]

the same timeframe as the population of copyright cases $(78$ cases registered between 1998 and 2015). We observe that some countries are active litigators before the CJEU but do not seem to be focussing specifically on copyright law. This is the case, for example, for France, Italy, and Germany. Conversely, countries with a high ratio between overall litigation and copyright litigation seem to invest specifically on this policy issue. These countries include the

\begin{tabular}{|l|r|}
\hline Country & Overall Submissions \\
\hline MT & 2 \\
\hline CZ & 48 \\
\hline PL & 80 \\
\hline FI & 95 \\
\hline IE & 58 \\
\hline LT & 37 \\
\hline PT & 126 \\
\hline FR & 503 \\
\hline ES & 374 \\
\hline UK & 457 \\
\hline EL & 146 \\
\hline AT & 470 \\
\hline SK & 32 \\
\hline HU & 121 \\
\hline IT & 1054 \\
\hline BE & 529 \\
\hline RO & 109 \\
\hline NL & 604 \\
\hline SE & 121 \\
\hline BG & 83 \\
\hline DE & 1478 \\
\hline DK & 134 \\
\hline
\end{tabular}

\begin{tabular}{|l|r|}
\hline Country & Copyright Submissions \\
\hline MT & 1 \\
\hline CZ & 11 \\
\hline PL & 15 \\
\hline FI & 14 \\
\hline IE & 7 \\
\hline LT & 4 \\
\hline PT & 12 \\
\hline FR & 24 \\
\hline ES & 17 \\
\hline UK & 19 \\
\hline EL & 6 \\
\hline AT & 15 \\
\hline SK & 1 \\
\hline HU & 3 \\
\hline IT & 24 \\
\hline BE & 10 \\
\hline RO & 2 \\
\hline NL & 10 \\
\hline SE & 2 \\
\hline BG & 1 \\
\hline DE & 16 \\
\hline DK & 1 \\
\hline
\end{tabular}

\begin{tabular}{|l|r|}
\hline Country & Ratio C/O \\
\hline MT & $50 \%$ \\
\hline CZ & $23 \%$ \\
\hline PL & $19 \%$ \\
\hline FI & $15 \%$ \\
\hline IE & $12 \%$ \\
\hline LT & $11 \%$ \\
\hline PT & $10 \%$ \\
\hline FR & $5 \%$ \\
\hline ES & $5 \%$ \\
\hline UK & $4 \%$ \\
\hline EL & $4 \%$ \\
\hline AT & $3 \%$ \\
\hline SK & $3 \%$ \\
\hline HU & $2 \%$ \\
\hline IT & $2 \%$ \\
\hline BE & $2 \%$ \\
\hline RO & $2 \%$ \\
\hline NL & $2 \%$ \\
\hline SE & $2 \%$ \\
\hline BG & $1 \%$ \\
\hline DE & $1 \%$ \\
\hline DK & $1 \%$ \\
\hline
\end{tabular}

Figure 5: Control: Overall litigation rates compared to copyright litigation rates [Colour figure can be viewed at wileyonlinelibrary.com] 
Czech Republic, Poland and Finland. ${ }^{89}$ Figure 5 illustrates the pattern by calculating for each Member State the ratio of copyright interventions as a share of overall litigation before the Court of Justice.

When we consider the country submissions for each of the clusters identified in the methodology section above, we have another interesting picture. Some countries, despite their overall involvement in EU litigation and their extremely high involvement in copyright litigation, are in fact interested only in a limited number of legal issues. It might be suggested that they intervene only on topics that are relevant for their domestic policy and where they hope to make an impact. Figure 6 shows the copyright submissions from each country broken down by main legal concept in the case.

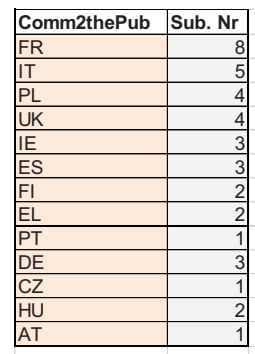

Figure 6: Repeat Players on individual Legal Concepts [Colour figure can be viewed at wileyonlinelibrary.com]

If we consider the number of interventions of the top three copyright litigators, France, Italy and the UK, within the five legal copyright issues in our dataset, we observe the following: France appears most interested in Communication to the Public and the Distribution right; it is also invested in Fair compensation for private reproduction (Levies) but not at all in Copyright Exceptions and the responsibility of Intermediaries. Italy, likewise, seems to be interested (and ready to invest) in Communication to the Public, Copyright Exceptions and Intermediaries, while neglecting the other issues. The UK, on the contrary, allocates its investments among all these issues. The behaviour of other countries, carefully picking their interventions, is interesting. See for example the focus on Levies from Finland and Spain.

The brief analysis above suggests that governments' interventions in European case law is - at least in most cases - strategic; countries tend to invest most in topics relevant for their domestic policies. However, this picture needs to be read in the context of routine intervention of some countries in cases where officials are mandated to intervene in preliminary references originating from their own country. ${ }^{90}$

89 The lower the number of interventions, the less reliable the figures. See for example, Malta.

90 When we presented this analysis back to the agents and civil servants of Member States who had cooperated with our study, they confirmed the distinction between mandated and strategic interventions. For further details, see qualitative validation exercise at the end of the following section. 


\section{THE PERFORMANCE OF GOVERNMENT SUBMISSIONS AND THEIR SUPPORT OF RIGHTHOLDERS OR USERS}

\section{Descriptive data}

Following the identification of Repeat Players in copyright and their propensity and specific interest in copyright litigation, we now move to the core of this study. Here we aim to analyse the success rate of the written observations of each country and the proximity of their arguments to the positions of rightholders or users. To this end, we have extracted all copyright-related questions asked within preliminary references and the suggested answers proposed by the submissions of the intervening parties. $^{91}$

Our sample of 42 cases dealing with the five most contested ('recurrent') copyright issues has been coded by each legal question asked in the preliminary reference to the Court and each suggested answer by the parties, the AG and the intervening third parties. 147 questions were identified, to which a variable number of governments suggested an answer. Most of these answers were coded with a Yes or No. When the suggested answer could not be reduced to a Yes/No answer, it was coded with an X. Only the answers coded with a Yes or No were considered for statistical computation.

Overall, from the sources discussed in detail in the methodology section (AG Opinions, Court Registry, Agents, Freedom of Information requests) we retrieved a total of 584 suggested answers within the sample of 42 cases and excluding the countries that made only one submission (such as Romania, Norway, Sweden, Latvia). In addition to these, the total number of questions not answered with a Yes or No (and therefore coded with an X) is $136 .{ }^{92}$ Figure 7 provides an example of the coding of a case.

Eva-Maria Painer v Standard Verlags GmbH (Painer) was a preliminary reference from Austria (decided by the CJEU in 2012). ${ }^{93}$ A number of German and Austrian newspapers, magazines and websites had published photographs of a girl who had escaped after being held in captivity for eight years. The photos were taken by Ms Painer (a photographer) while the girl was at nursery school before she was abducted in 1998 (aged 10). She was held captive until she escaped in 2006. This story had high resonance in the media.

In the columns, the following codes were used: $\mathrm{OP}=$ Opinion of the Advocate General; JU = Judgement of the Court; Rh = Answer in favour of Rightholder; Us = Answer in favour of User (including Intermediaries). The additional columns refer to Member States' positions, identified by

91 The questions are extracted from the Opinion of the Advocate General (AG) in a way requiring a Yes or No answer. We have chosen to elaborate the questions from the Opinion of the AG and not from the Application because the structure of the questions and answers in the ruling mostly follows the pattern of questions as reorganised by the AG. Also, the suggested answers in the written observations cited by the AG, which forms the basis for this part of the analysis, follow the same structure.

92 There are $30(=5.8 \%)$ missing data points where neither freedom of information requests nor reconstruction from other sources produced sufficient information to code a country's suggested answer to a question.

93 Case C-145/10 Eva-Maria Painer v Standard Verlags GmbH ECLI:EU:C:2013:138. 


\begin{tabular}{|c|c|c|c|c|c|c|c|c|}
\hline $\mathrm{C}-145 / 10$ Painer (RH) vs Standard Verlags $\mathrm{GmbH}$ et al (L & & & & & & & & \\
\hline QUESTION & OP & $\mathrm{JU}$ & $\mathrm{RH}$ & US & AT & ES & IT & EUComm \\
\hline $\begin{array}{l}\text { Q4 Have portrait photos weaker copyright protection (Art } 1 \& 5 \\
\text { InfoSoc and Human Rights?) }\end{array}$ & $\mathrm{N}$ & $\mathrm{N}$ & $\mathrm{N}$ & $\mathrm{x}$ & $\mathrm{N}$ & $\mathrm{N}$ & $\mathrm{N}$ & $\mathrm{N}$ \\
\hline $\begin{array}{l}\text { Q3a Does Art 5(3)(e) applies or an official order of publication } \\
\text { must come from the authorities(Y)? }\end{array}$ & $\mathrm{N}$ & $\mathrm{Y}$ & $\mathrm{Y}$ & $\mathrm{N}$ & $\mathrm{N}$ & $\mathrm{Y}$ & & $\mathrm{N}$ \\
\hline $\begin{array}{l}\text { Q3b Can newpapers decide for themselves whether it is a } \\
\text { matter of public security? }\end{array}$ & $\mathrm{N}$ & $\mathrm{N}$ & $\mathrm{N}$ & $\mathrm{Y}$ & $\mathrm{N}$ & $\mathrm{N}$ & & $\mathrm{N}$ \\
\hline $\begin{array}{l}\text { Q3c Must the newspaper expressly call for help from the reader } \\
\text { for identification? }\end{array}$ & $\mathrm{x}$ & $\mathrm{x}$ & $\mathrm{Y}$ & $\mathrm{N}$ & & $\mathrm{Y}$ & & $\mathrm{x}$ \\
\hline $\begin{array}{l}\text { Q2a Is Art } 5(3)(d) \text { InfoSoc applicable where the medium in which } \\
\text { the quotation can be found is not itself afforded copyright } \\
\text { protection? }\end{array}$ & $\mathrm{Y}$ & $\mathrm{Y}$ & $\mathrm{N}$ & $\mathrm{Y}$ & $\mathrm{Y}$ & $\mathrm{Y}$ & $\mathrm{N}$ & $\mathrm{Y}$ \\
\hline $\begin{array}{l}\text { Q2b Is Art 5(3)(d) InfoSoc applicable where the author of the } \\
\text { published photo is not named in the reports? }\end{array}$ & $\mathrm{N}$ & $\mathrm{N}$ & $\mathrm{N}$ & $\mathrm{Y}$ & $\mathrm{N}$ & $\mathrm{N}$ & $\mathrm{N}$ & $\mathrm{N}$ \\
\hline Suggested answer & & & & & 5 & 6 & 3 & 5 \\
\hline Match Ruling & & & & & 4 & 5 & 2 & 4 \\
\hline Match RH & & & & & 3 & 5 & 3 & 3 \\
\hline Match US & & & & & 2 & 1 & 2 & 2 \\
\hline Not Answered & & & & & & & & 1 \\
\hline Missing Data Points & & & & & 1 & & 3 & \\
\hline
\end{tabular}

Figure 7: Coding example [Colour figure can be viewed at wileyonlinelibrary.com]

country code. The last column codes the suggested answers by the European Commission.

In the bottom six rows, the answers were coded for 'match with ruling', i.e. if the suggested answer from a Member State or the European Commission corresponded to the answer given by the Court in the ruling. This allows us to establish a relationship between the variables for the interventions of each third party and the variables for the outcome of each case. In addition, the suggested answers and the rulings by the Court were coded for 'match with Rightholder' and 'match with User' (which we defined widely to include Intermediaries). Users and Intermediaries have been grouped together because both end-users and intermediaries (such as platforms) oppose the expansion of rights. Where the scope of rights is at issue, jurisprudentially this is clearest way to capture the position of the intervening third parties (Member States and Commission). Binary coding also has the additional benefit of producing larger sample sizes for statistical analysis.

In the following master table (Figure 8), which consolidates all data points, these matches have been ordered by legal concept under discussion. The table identifies the number of matches with the Ruling, with the Rightholder and with the User/Intermediary. The percentages give the ratio between 'matches with ruling' and 'number of submitted answers'. The ratio also reflects the suggested answers that did not match with the ruling. Therefore, in order to assess the performance of each government the percentages are the key indicators, not the absolute numbers. ${ }^{94}$

94 Where there are low numbers of interventions or a lack of data points, percentages need to be treated with caution (see for example the case of Hungary). Since the numbers in the dataset 


\begin{tabular}{|c|c|c|c|c|c|c|c|c|c|c|c|c|c|c|c|c|c|c|}
\hline Communication to the Public (Art 3-Art 8 InfoS & AT & $\mathrm{BE}$ & $\mathrm{CZ}$ & $\mathrm{DE}$ & EL & ES & $\mathrm{FI}$ & FR & $\mathrm{HU}$ & $\mathrm{IE}$ & IT & NL & $\mathrm{PL}$ & UK & PT & LT & \multicolumn{2}{|c|}{ EUCom Ruling } \\
\hline Match with Ruling & $63 \%$ & & \begin{tabular}{|l|}
$64 \%$ \\
\end{tabular} & $50 \%$ & $0 \%$ & $29 \%$ & $67 \%$ & $59 \%$ & $100 \%$ & $42 \%$ & $60 \%$ & & $60 \%$ & $50 \%$ & $38 \%$ & & $48 \%$ & \\
\hline Match with Right Holder & $75 \%$ & & $73 \%$ & $50 \%$ & $0 \%$ & $43 \%$ & $83 \%$ & $72 \%$ & $75 \%$ & $8 \%$ & $50 \%$ & & $80 \%$ & $70 \%$ & $13 \%$ & & $36 \%$ & $60 \%$ \\
\hline Match with User & $38 \%$ & & $27 \%$ & $43 \%$ & $100 \%$ & $29 \%$ & $17 \%$ & $25 \%$ & $25 \%$ & $92 \%$ & $40 \%$ & & $20 \%$ & $20 \%$ & $88 \%$ & & $56 \%$ & $48 \%$ \\
\hline & & & & & & & & & & & & & & . & & & . & \\
\hline Match with Ruling & 5 & 0 & 7 & 7 & 0 & 2 & 4 & 19 & 4 & 5 & 6 & 0 & 3 & 5 & 3 & 0 & 24 & \\
\hline Match with Right Holder & 6 & 0 & 8 & 7 & 0 & 3 & 5 & 23 & 3 & 1 & 5 & 0 & 4 & 7 & 1 & 0 & 18 & 29 \\
\hline Match with User & 3 & 0 & 3 & 6 & 5 & 2 & 1 & 8 & 1 & 11 & 4 & 0 & 1 & 2 & 7 & 0 & 28 & 23 \\
\hline Data Points & 8 & 0 & 11 & 14 & 5 & 7 & 6 & 32 & 4 & 12 & 10 & 0 & 5 & 10 & 8 & 0 & 50 & 48 \\
\hline Cases & 2 & & 2 & 3 & 2 & 3 & 2 & 9 & 2 & 3 & 4 & & 3 & 4 & 2 & & 15 & 15 \\
\hline & & & & & & & & & & & & & & & & & & \\
\hline Fair compensation (private copy) (A5.2(b) Infos & & & & & & & & & & & & & & & & & & \\
\hline Match with Ruling & $37 \%$ & $20 \%$ & $33 \%$ & $50 \%$ & $33 \%$ & $38 \%$ & $64 \%$ & $68 \%$ & & $100 \%$ & $100 \%$ & $58 \%$ & $0 \%$ & $63 \%$ & $100 \%$ & $63 \%$ & $81 \%$ & \\
\hline Match with Right Holder & $84 \%$ & $60 \%$ & $67 \%$ & $70 \%$ & $50 \%$ & $33 \%$ & $45 \%$ & $58 \%$ & & $0 \%$ & $0 \%$ & $50 \%$ & $0 \%$ & $13 \%$ & $0 \%$ & $25 \%$ & $30 \%$ & $37 \%$ \\
\hline Match with User & $26 \%$ & $20 \%$ & $33 \%$ & $20 \%$ & $50 \%$ & $48 \%$ & $50 \%$ & $58 \%$ & & $50 \%$ & $100 \%$ & $50 \%$ & $0 \%$ & $88 \%$ & $88 \%$ & $75 \%$ & $70 \%$ & $57 \%$ \\
\hline & & & & & & & & & & & 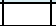 & 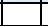 & 1 & 峝 & 1 & 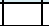 & 常 & \\
\hline Match with Ruling & 7 & 1 & 1 & 5 & 2 & 8 & 14 & 13 & 0 & 2 & 3 & 7 & 2 & 5 & 8 & 5 & 22 & \\
\hline Match with Right Holder & 16 & 3 & 2 & 7 & 3 & 7 & 10 & 11 & o & of & o & 6 & 5 & 1 & 0 & 2 & 8 & 13 \\
\hline Match with User & 5 & 1 & 1 & 2 & 3 & 10 & 11 & 11 & 0 & 1 & 3 & 6 & 1 & 7 & 7 & 6 & 19 & 20 \\
\hline Data Points & 19 & 5 & 3 & 10 & 6 & 21 & 22 & 19 & 0 & 2 & 3 & 12 & 7 & 8 & 8 & 8 & 27 & 35 \\
\hline Cases & 7 & 2 & 2 & 2 & 2 & 5 & 7 & 4 & & 2 & 2 & 3 & 2 & 3 & 3 & 3 & 9 & 9 \\
\hline & & & & & & & & & & & & & & & & & & \\
\hline Distribution Rights (Dist2thePub) (Art 4 lnfoSoc & & & & & & & & & & & & & & & & & & \\
\hline Match with Ruling & & & $100 \%$ & & & $100 \%$ & & $100 \%$ & & & & & $17 \%$ & $0 \%$ & & & $78 \%$ & \\
\hline Match with Right Holder & & & $100 \%$ & & & $100 \%$ & & $100 \%$ & & & & & $67 \%$ & $0 \%$ & & & $56 \%$ & $78 \%$ \\
\hline Match with User & & & $0 \%$ & & & $0 \%$ & & $0 \%$ & & & & & $33 \%$ & $100 \%$ & & & $44 \%$ & $22 \%$ \\
\hline & & & & & & & & & & & & & & & & & & \\
\hline Match with Ruling & 0 & 0 & 1 & 0 & 0 & 1 & 0 & 3 & 0 & 0 & 0 & 0 & 1 & 0 & 0 & 0 & 7 & \\
\hline Match with Right Holder & 0 & 0 & 1 & 0 & 0 & 1 & 0 & 3 & 0 & 0 & 0 & 0 & 4 & 0 & 0 & 0 & 5 & 7 \\
\hline Match with User & 0 & 0 & 0 & 0 & 0 & 0 & 0 & 0 & 0 & 0 & 0 & 0 & 2 & 2 & 0 & 0 & 4 & 2 \\
\hline Data Points & 0 & 0 & 1 & 0 & 0 & 1 & 0 & 3 & 0 & 0 & 0 & 0 & 6 & 2 & 0 & 0 & 9 & 9 \\
\hline Cases & & & 1 & & & 1 & & 2 & & & & & 3 & 1 & & & 6 & 6 \\
\hline & & & & & & & & & & & & & & & & & & \\
\hline Copyright Exceptions (Art 5 InfoSoc) & & & & & & & & & & & & & & & & & & \\
\hline Match with Ruling & $35 \%$ & $100 \%$ & & $100 \%$ & & $33 \%$ & $75 \%$ & & & & $71 \%$ & & $100 \%$ & $100 \%$ & & & $64 \%$ & \\
\hline Match with Right Holder & $29 \%$ & $20 \%$ & & $50 \%$ & & $100 \%$ & $50 \%$ & & & & $57 \%$ & & $0 \%$ & $0 \%$ & & & $54 \%$ & $56 \%$ \\
\hline Match with User & $71 \%$ & $80 \%$ & & $50 \%$ & & $0 \%$ & $50 \%$ & & & & $71 \%$ & & $100 \%$ & $100 \%$ & & & $39 \%$ & $44 \%$ \\
\hline & & & & & & & & & & & & & & & & & & \\
\hline Match with Ruling & 6 & 5 & 0 & 4 & 0 & 1 & 3 & 0 & 0 & 0 & 5 & 0 & 3 & 1 & 0 & 0 & 18 & \\
\hline Match with Right Holder & 5 & 1 & 0 & 2 & 0 & 3 & 2 & 0 & 0 & 0 & 4 & 0 & 0 & 0 & 0 & 0 & 15 & 14 \\
\hline Match with User & 12 & 4 & 0 & 2 & 0 & 0 & 2 & 0 & 0 & 0 & 5 & 0 & 3 & 1 & 0 & 0 & 11 & 11 \\
\hline Data Points & 17 & 5 & 0 & 4 & 0 & 3 & 4 & 0 & 0 & 0 & 7 & 0 & 3 & 1 & 0 & 0 & 28 & 25 \\
\hline \begin{tabular}{|l|l} 
Cases \\
\end{tabular} & 2 & 1 & & 1 & & 2 & 1 & & & & 4 & & 2 & 1 & & & 6 & 6 \\
\hline & & & & & & & & & & & & & & & & & & \\
\hline Intermediaries (Art 8 Enforcement Directive) & & & & & & & & & & & & & & & & & & \\
\hline Match with Ruling & $33 \%$ & $100 \%$ & $100 \%$ & & & & $50 \%$ & & & & $60 \%$ & $60 \%$ & $100 \%$ & $60 \%$ & & & $80 \%$ & \\
\hline Match with Right Holder & \#\#\#\# & $0 \%$ & $33 \%$ & & & & $50 \%$ & & & & $80 \%$ & $40 \%$ & $50 \%$ & $60 \%$ & & & $50 \%$ & $36 \%$ \\
\hline Match with User & $0 \%$ & $100 \%$ & $33 \%$ & & & & $50 \%$ & & & & $40 \%$ & $40 \%$ & $50 \%$ & $40 \%$ & & & $50 \%$ & $55 \%$ \\
\hline & & & & & & & & & & & & & & & & & & \\
\hline Match with Ruling & 1 & 2 & 3 & 0 & 0 & 0 & 1 & 0 & 0 & 0 & 3 & 3 & 4 & 3 & 0 & 0 & 8 & \\
\hline Match with Right Holder & 3 & 0 & 1 & 0 & 0 & 0 & 1 & 0 & 0 & 0 & 4 & 2 & 2 & 3 & 0 & 0 & 5 & 4 \\
\hline Match with User & 0 & 2 & 1 & 0 & 0 & 0 & 1 & 0 & 0 & 0 & 2 & 2 & 2 & 2 & 0 & 0 & 5 & 6 \\
\hline Data Points & 3 & 2 & 3 & 0 & 0 & 0 & 2 & 0 & 0 & 0 & 5 & 5 & 4 & 5 & 0 & 0 & 10 & 11 \\
\hline Cases & 1 & 2 & 2 & & & & 2 & & & & 5 & 3 & 2 & 3 & & & 6 & 6 \\
\hline & & & & & & & & & & & & & & & & & & \\
\hline$\overline{\text { TOTAL }}$ & AT & $\mathrm{BE}$ & $\mathrm{CZ}$ & $\mathrm{DE}$ & EL & ES & $\mathrm{FI}$ & FR & $\mathrm{HU}$ & IE & IT & $\mathrm{NL}$ & $\mathrm{PL}$ & UK & PT & LT & EUCom & Ruling \\
\hline Match with Ruling/Data Points & $40 \%$ & $67 \%$ & $67 \%$ & $57 \%$ & $18 \%$ & $38 \%$ & $65 \%$ & $65 \%$ & $100 \%$ & $50 \%$ & $68 \%$ & $59 \%$ & $52 \%$ & $54 \%$ & $69 \%$ & $63 \%$ & $60 \%$ & \\
\hline Match with Right Holder/Data Points & $64 \%$ & $33 \%$ & $67 \%$ & $57 \%$ & $27 \%$ & $44 \%$ & $53 \%$ & $69 \%$ & $75 \%$ & $7 \%$ & $52 \%$ & $47 \%$ & $60 \%$ & $42 \%$ & $6 \%$ & $25 \%$ & $41 \%$ & $52 \%$ \\
\hline Match with User/Data Points & $43 \%$ & $58 \%$ & $28 \%$ & $36 \%$ & $73 \%$ & $38 \%$ & $44 \%$ & $35 \%$ & $25 \%$ & $86 \%$ & $56 \%$ & $47 \%$ & $36 \%$ & $54 \%$ & $88 \%$ & $75 \%$ & $54 \%$ & $48 \%$ \\
\hline & & & & & & & & & & & & & & & & & & \\
\hline MatchRul=Rh & 10 & 1 & 8 & 10 & 1 & 9 & 10 & 25 & 2 & 2 & 7 & 2 & 7 & 4 & 0 & 0 & 37 & \\
\hline MatchRul=Us & 5 & 6 & 3 & 6 & 1 & 6 & 11 & 12 & 1 & 1 & 7 & 2 & 6 & 9 & 6 & 6 & 35 & \\
\hline Match with Ruling & 19 & 8 & 12 & 16 & 2 & 12 & 22 & 35 & 4 & 7 & 17 & 10 & 13 & 14 & 11 & 5 & 75 & \\
\hline Match with Right Holder & 30 & 4 & 12 & 16 & 3 & 14 & 18 & 37 & 3 & 1 & 13 & 8 & 15 & 11 & 1 & 2 & 51 & 67 \\
\hline Match with User & 20 & 7 & 5 & 10 & 8 & 12 & 15 & 19 & 1 & 12 & 14 & 8 & 9 & 14 & 14 & 6 & 67 & 62 \\
\hline Data Points & 47 & 12 & 18 & 28 & 11 & 32 & 34 & 54 & 4 & 14 & 25 & \begin{tabular}{|c|}
17 \\
\end{tabular} & 25 & 26 & 16 & 8 & 124 & 128 \\
\hline \begin{tabular}{|l|} 
Cases \\
\end{tabular} & 12 & 5 & 7 & 6 & 4 & 11 & 12 & 15 & 2 & 5 & 15 & 6 & 12 & 12 & 5 & 3 & 42 & 42 \\
\hline
\end{tabular}

Figure 8: Government submissions' match with Rightholder or User interests and CJEU Ruling (sample of 42 cases, discussing five 'recurrent' legal issues) [Colour figure can be viewed at wileyonlinelibrary.com]

\section{Analysis}

The following analysis focusses on general trends that emerge for the juridification of the European policy process regarding the five 'recurrent' legal

are too low to test for statistical significance, we address this issue by constructing a Cartesian diagram. See Figure 9 below. 
issues (which mark a normative void in copyright law). A fuller doctrinal context for each the five legal issues, and of the interests at the heart of individual Government submissions is given in Appendix II (see Supporting Information).

The issue of Communication to the public is particularly contentious. Consensus among Member States' observations is rare, and it is limited to particularly simple features of this concept (acte clair). For example, it is uncontroversial that installation of TV sets in hotel rooms does not amount to Communication to the public, and that Internet Service Providers (ISPs) are intermediaries in the light of Article 8 of the InfoSoc Directive. On most nuances surrounding the interpretation of the concept of Communication to the public, the written observations of governments and EU Commission disagree. SGAE, Phonographic Performance and GS Media are among the most notable examples of this disagreement. The position of France, among the submitting governments, is to be noted as being often in disagreement with the others. However, this is not as to say that the other countries agree among themselves on every point. The impact of governments' observations on the rulings on this specific topic is also erratic and difficult to pin down. Sometimes the Court follows the opinion of the majority (as for example in SCF); on other occasions the ruling follows the minority (as for example in GS Media). This indicates that the influence of a Member State does not necessarily depend on the number of its allies. The number of submissions from a given government on a given topic, combined with its success rate (number of matches between its suggested answers and the ruling) gives a more reliable indicator.

In the case of Communication to the public, the figures computed in Figure 8 reveal France as the most influential country by some distance. France's submissions produced 32 suggested answers (data points), of which 19 (59 per cent) match the Court's ruling. Other frequently intervening countries, such as Germany (14 data points), Ireland (12), Italy (10), and the UK (10) have each produced less than half the number of submissions of France, and none exceed a match rate of 50 per cent with the Court's ruling. Intervening countries sometimes take the same stance, and they tend to succeed mostly when they reach critical mass (e.g., when they coordinate their efforts: see $S C F$ ) or when the question is not particularly controversial (and France does not intervene).

The legal issue of Fair compensation (levies) is the one that received the highest attention from Member States, with the highest total number of submissions (60) in our sample, each containing multiple suggested answers (144 data points). Finland (22 data points), Spain (21), France (19) and Austria (11), among these countries, are the most active. Their success before the Court is not consistent. Generally, Spain pushes for broader country self-determination and more flexibility in choosing the features of the levy systems, whereas Finland vouches for a narrower interpretation of the directive, for example by supporting compensation only for 'personal' copies. Overall the Court favours this latter interpretation. Other countries, such as Germany (nine data points) and the UK (eight data points), rarely intervene on this legal concept, but when they do so their suggested answers are often accepted by the Court (Germany: 59 per cent match with ruling; UK: 63 per cent). France keeps an intermediate stance between Spain and Finland: it normally pushes for a strong protection of 
the rightholder, and it often succeeds in convincing the Court of its arguments (68 per cent match).

With respect to the Distribution right, Article 4 of the InfoSoc Directive is broadly interpreted by the Court, which protects the exclusive right of the European owner against infringement coming from non-EU countries. There seems to be a consensus on the point that international exhaustion does not apply and works sold or offered on foreign web sites are infringing, as well as works manufactured in countries with temporary exemption from copyright protection. ${ }^{95}$ With the exception of Poland (six data points), which seldom manages to convince the Court (17 per cent match), and the UK (only two data points, no match), other submitting countries suggest answers that are in line both with the Ruling and the Opinion (100 per cent match for Czech Republic, Spain and France).

On Exceptions, we can detect a rather balanced approach of the Court (as confirmed by our previous research ${ }^{96}$ ) with a number of broad interpretations (11, coded as favouring users) offset by a slightly larger number (14) of narrow interpretations. The data on the submitting countries is insufficient to determine with a degree of reliability which country favours a broad interpretation and which country supports a narrow position. The observable pattern suggests that the majority of the countries are for a narrow interpretation of copyright exceptions, but their degree of success in front of the Court appears erratic. Italy (four submissions, seven data points) and Austria (two submissions, 17 data points) are the most active Member States, achieving a match rate of 35 per cent (Austria) and 71 per cent (Italy).

Finally, the case law on Intermediaries (Article 8, Enforcement Directive) is very limited in the sample, with only 20 submissions from Member States in total, making it difficult to identify patterns.

Given that the numbers of observations in our sample are generally too small for further statistical analysis, we now explore the Cartesian diagram (Figure 9) as a visualisation technique for the data set as a whole. ${ }^{97}$ For constructing the diagram, the Yes/No coding has been translated into numerical values. Each 'match with ruling' was assigned a value of 1, whereas to each suggested answer not matched in the ruling the value of -1 was assigned. Likewise, to each 'match with the rightholder' the value of 1 was assigned and to each position unfavourable to the rightholder (i.e. supporting user or intermediary positions) the value of -1 was assigned. These latter numbers differ slightly from those presented in Figure 8 because the cases in which rightholders and users held the same position (very few occurrences) where not computed. The Cartesian diagram enables an overview of the relative position of the Member States and the Commission to each other, and of their performance even in the cases of low numbers of observations. The 'investment' in copyright litigation is

95 See the case of overlapping design and copyright protection as in C-168/09 Flos ECLI:EU:C:2011:29. See generally L. Bently, 'The return of industrial copyright?' (2012) 34 EIPR 654.

96 n 5 above, 58 .

97 The authors are grateful to the economist Moritz Mosenhauer who suggested the Cartesian diagram as a visualisation of our data. 


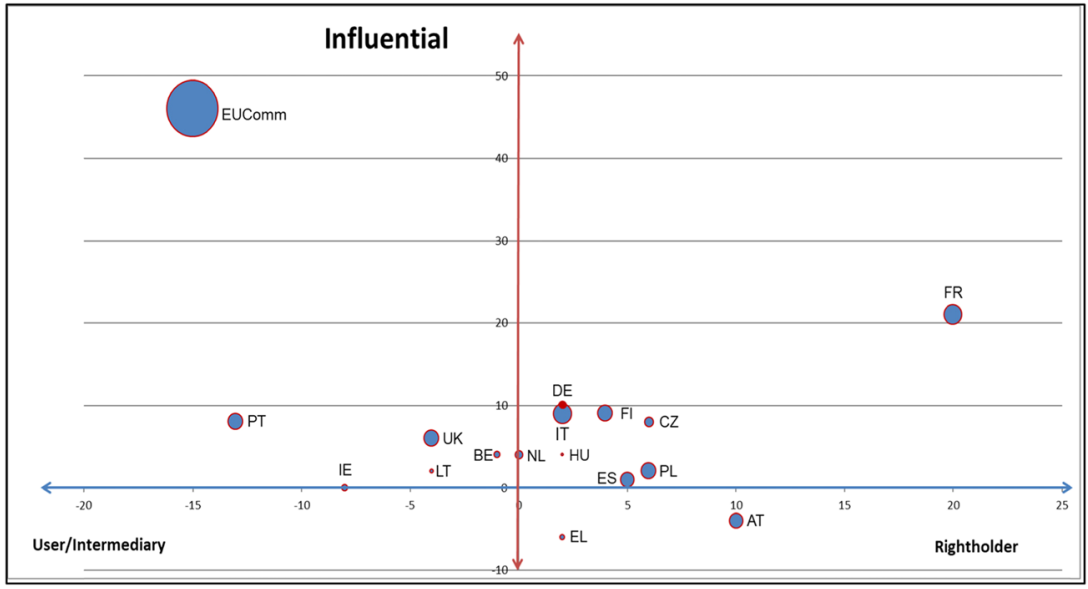

Figure 9: Cartesian diagram illustrating Member State/Commission influence and promotion of Rightholder or User/Intermediary interests [Colour figure can be viewed at wileyonlinelibrary.com]

conveyed by proxy with the number of written observations for each country, displayed in the graph by the size of the circles (Figure 9).

The most striking feature exposed by this diagram is the closeness of the Commission to the Court. Submissions by the Commission correlate highly with the Court's rulings and the Commission appears to intervene particularly effectively on behalf of user interests. ${ }^{98}$ A second important finding is that, collectively, the submissions by Members States are above the influence line, correctly predicting the Court's rulings. This aligns with arguments from the political science literature that the Court needs to maintain political legitimacy. ${ }^{99}$

France stands out for its high matches with the Court's decisions (indicating potentially a superior level of influence) and for its support for rightholders. Finland is also very effective, but more balanced in its choice of support, as is Germany. Austria and Greece appear to be the least successful countries. Interesting is the effective performance of some other players such as the Czech Republic and Portugal. As for the balance between rightholders and users, the evidence here suggests a prevalence of rightholder support, counterbalanced by the strong presence of the EU Commission in favour of user interests. Few countries, among them Portugal, Ireland and the United Kingdom, regularly advance the users' (and intermediaries') perspective.

This analysis is particularly relevant in the current exceptional European context, which will exclude from this picture the participation of the United Kingdom. ${ }^{100}$ While the above scenario, as it stands, shows an overall - yet

98 This has been further investigated in research funded by the International Federation of the Phonographic Industry (IFPI): E. Rosati, 'What Does the European Commission Make of the EU Copyright Acquis When It Pleads Before the CJEU? The Legal Service's Observations in Digital/Online Cases' European Law Review (forthcoming).

99 n 2 above; $n 11$ above.

100 R. Arnold, L. Bently, E. Derclaye and G. Dinwoodie, 'The Legal Consequences of Brexit Through the Lens of IP Law' (2017) 101 Judicature 65. 
delicate - balance, the disappearance of the United Kingdom's voice before the Court is likely to have consequences for the recognition of interests of copyright users and intermediaries.

\section{Qualitative validation}

Following completion of the dataset, we offered the tables of interventions and matches, and the analytic perspective of the Cartesian diagram back to the Court Agents and Civil Servants we had contacted during the study. We received responses from nine countries: Czech Republic, France, Germany, Ireland, The Netherlands, Poland, Portugal, Spain and Sweden. All indicated that they recognised the patterns we had identified, and many found the analytic approach extremely interesting and recommended wide dissemination to facilitate discussion.

We received some indications about the underlying reasons for decisions to intervene in cases before Court of Justice. As expected, providing resources to intervene is indeed seen as a cost that needs to be justified in terms of national policy priorities. For example, it was observed that a relatively low number of preliminary references originating from their own country 'could sometimes limit our ability to shape the Court jurisprudence'. This however could be compensated by 'a strong commitment to be playing an important role in these debates'. Member States do make decisions if and how to steer the Court.

The feedback from France disagreed with the distinction between Rightholders and Users (as including Intermediaries) we employed for analysing if an intervention matched the Court's ruling. France suggested that the interests of online platforms are not aligned with those of users. The position of France on the side of rightholders should not be understood as targeting users. Rather France was attempting to strike a balance between the rights of the copyright owner and the economic advantages gained by the intermediaries (while vesting the interests of users). ${ }^{101}$ Mindful of this argument, we argue above that the binary coding (Rightholders vs Users) is a pragmatic simplification to achieve a workable sample size but also compelling in the specific context of copyright law where the scope of rights is at issue. Coding a decision as permitting behaviour that may otherwise fall under the control of copyright owners is simply a negative descriptor. It does not imply that the outcome serves only one set of interests, nor that the interests of users and intermediaries are the same.

\section{CONCLUSION}

Our series of studies on the CJEU's copyright jurisprudence was initially motivated by a specific normative void that seemed to be filled by judicial policy

101 Feedback from France, on file with the authors. 
making. But when we lifted the lid in our underpinning study ${ }^{102}$ revealing the workings of the Court, it became clear that the empirical approach would have much wider theoretical implications.

The production of a dataset that tracks the influence of Member States on the evolution of jurisprudence in a specific subject domain opens a new perspective on the making of transnational law. Our method makes it possible to construct influence rankings, quantifying the relationship between Member States, the European Commission and the Court of Justice in the juridification of policy. This is extendable to other areas of law and enables a potentially transformative advance in the understanding of the 'production of Europe'.

In the specific area of copyright law, the study allowed us to target the forces moving CJEU jurisprudence. We found that copyright interventions revolve mainly around the concepts of Communication to the public and Copyright levies (fair compensation for private copying), with Exceptions, the Distribution right and Intermediaries also attracting considerable attention. The analysis of recurrent legal issues before the Court of Justice confirms that there are areas of copyright law vulnerable to strategic litigation, arguably because there is room for alternative policy paths without introducing legislation.

We found that through written observations, governments aim to steer the Court towards rulings in line with their respective policies. Member States most invested in copyright law are the dominant litigators of the acquis communautaire in general (France: 15 out of 42 cases in our sample, Italy: 15 cases, the UK: 12 cases), although there are other Member States that invest disproportionately in shaping the evolution of copyright law (Czech Republic: seven cases, The Netherlands: six, Portugal: five, Belgium: five).

Some governments' interventions are highly skewed, addressing repeatedly very specific copyright issues, which are presumably relevant for their own domestic policies. France for example seems to be particularly interested in the concept of Communication to the public, and in Fair compensation for private copying (Levies). Italy appears particularly interested in Exceptions and Intermediaries, while the UK allocates its investment in litigation across all copyright policy areas. Germany intervenes rarely (only in six cases in our sample) but is often successful when it does.

The impact of a written observation on the ruling of the Court is not only determined by critical mass, such as the number of submissions or the size of the country. More important appears to be the quality of the legal reasoning, as the relative success of smaller Repeat Players suggests (for example, Finland and Portugal). In this context, it is interesting to note the relative lack of success of certain governments that specifically invested in copyright litigation but who are seldom rewarded by the Court, such as Greece, Austria, Spain and Poland. Poland's written observations are often ignored both by the Advocate General and the Court for unclear reasons. Among avenues for future research, the reasons behind the copyright policy priorities of Member States 
and their success or failure translating these into juridical strategies warrant further scrutiny. Who is steering the policy of Member States?

Finally, it is tempting to read the above findings in the light of the political scenario predicting the loss of the United Kingdom as a strong litigator. Our evidence suggests that the UK carries weight in advancing the perspective of copyright users before the Court of Justice. There are not sufficient data points at this stage to test for statistical significance, but the pattern we identify points to a potential disturbance in the delicate balance between the interests of rightholders and users before the Court.

Viewed as a whole, the findings in the domain of copyright law are striking. The extraordinary closeness of the Commission to the Court of Justice stands out, as does the apparent desire by the Court to maintain legitimacy by moving with Member States' interventions (collectively understood). The Court is not free 'to produce Europe'.

\section{SUPPORTING INFORMATION}

Additional supporting information may be found online in the Supporting Information section at the end of the article.

APPENDIX I: Written Observations, and the Rules of Procedure of the Court of Justice of the European Union.

APPENDIX II: Member States' position on five key ('recurrent') copyright concepts. 